\title{
Have a nice trip
}

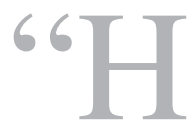

ave a nice trip." How those words still ring in my ears. They were Donna's last words to me. I had known her since the early 1990s, and I felt more inadequate hearing those words than at any time in the last decade and a half. She was ailing - struggling - and I was rushed. I needed to catch a plane and couldn't give her the time, let alone the words she deserved after all we had shared. I said I would see her on a Friday after I came back from Chicago (it was a Tuesday), fearing as I said this, that perhaps that would be too late.

Fifteen or so years ago, Donna was dying. Rheumatoid arthritis and interstitial lung disease were taking their toll. Over a series of visits, she had become more cyanosed. I found out from her son 15 years later that she had called her family together to say she likely had only another six months. Then, with a touch of pure serendipity and after other strategies had failed, somehow we decided to give it a go with cyclosporin A. I don't remember now how quickly she turned around, but I have told many a medical resident over the years how she went from blue to pink. Donna gained time. None of us knew back then how much time, but she continued to come to clinic from her home in Hubbards on Saint Marg Bay, and she never missed an appointment. She lived through her husband's unexpected sudden illness and early death, and her children growing up and leaving home.

In recent years, she would help out with teaching medical students, always smiling and with a story to tell. My abiding memory of her will be of her sitting cross-legged on her hospital bed on her penultimate admission, laughing away as she and I plotted to make sure

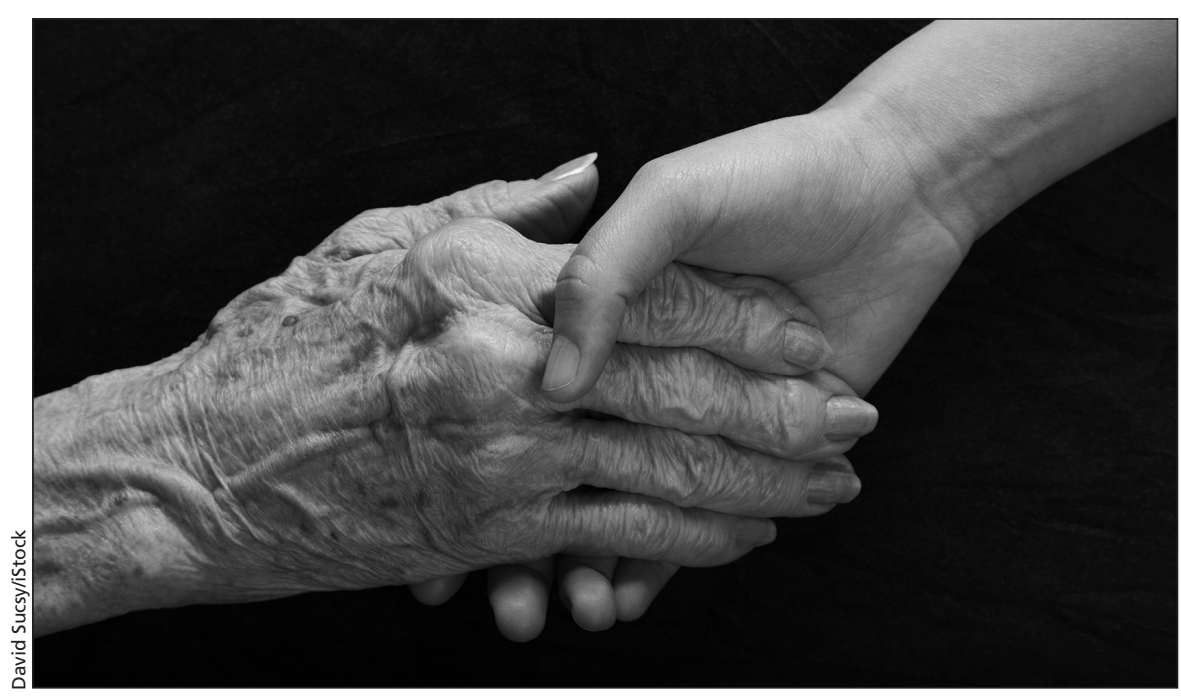

that none of my colleagues would sneak in and hijack her to teach their students instead.

In her last year, she finally agreed to long-term oxygen, but she still made the long journey to her mailbox. She handled everything with her characteristic stoicism, which impressed me more each time we met in clinic. Now, however, she was losing weight, and we both knew her condition was worsening. We had explored the possibility of lung transplantation much earlier, but that was not part of her plan. Hubbards was where she lived and wanted to stay. From time to time, I would ride my bike down the rails to trail from Halifax to Hubbards and wondered where she was on those sunny days.

And so to her last admission, still taking cyclosporin $\mathrm{A}$, but looking more frail than I had ever seen her. I had heard that she was in our intermediate care unit, so I dropped in to see her, but my timing was awful. Her adult children were with her, and I introduced myself. But for Donna, I had not enough time. I left the unit, caught my plane and came back to find her unconscious on the Friday, beyond any intervention. Two family friends were with her. I said that I would like to say some things to Donna, so they stepped out, and I said my thanks to her for all she had done for us over the years. Too little, too late, those words that I did not make time to say when she would have heard them for certain. I can but hope perhaps she heard something from me on that last day.

It is no consolation to know that, unbeknownst to me until after her death, she credited me with her life over the last 15 years. At the end, when I could and should have done so much more, I came up miserably short. Not so for Donna, who found both grace and words to bid me "Have a nice trip" as I left her bedside that day.

\section{Graeme M. Rocker DM \\ Faculty of Medicine, Dalhousie \\ University, Halifax, NS}

This is a true story. Donna's family has given their consent for this story to be told.

CMAJ 2016. DOI:10.1503/cmaj.150719 